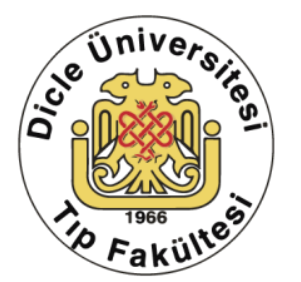

\title{
Evaluation Of 8-Hydroxy-2-Deoxyguanosine And Malondialdehyde Levels In First-Trimester Miscarriage: A Prospective Cohort Study
}

\author{
Reyhan Gündüz $^{1}$ iD , Mete Gurol Ugur² $^{\text {iD }}$, Neslihan Bayramoğlu Tepe ${ }^{2}$ iD, Hüseyin Çağlayan Özcan² ${ }^{2}$, \\ Özcan Balat $^{2}$ iD, Sevgi Sari Demir ${ }^{3}$ iD, Seyithan Taysi4 ${ }^{4}$
}

1 Dicle University, Faculty of Medicine, Department of Obstetrics and Gynecology, Diyarbakır, Turkey

2 Gaziantep University, Faculty of Medicine, Department of Obstetrics and Gynecology, Gaziantep, Turkey

3 Adana Medline Hospital, Department of Obstetrics and Gynecology, Adana, Turkey

4 Gaziantep University, Faculty of Medicine, Department of Medical Biochemistry, Gaziantep, Turkey

Received: 24.10.2019; Revised: 02.01.2020; Accepted: 22.01.2020

\begin{abstract}
Objective: This study was aimed to evaluate 8-hydroxy-2-deoxyguanosine (8-OHdG) and malondialdehyde (MDA) levels in patients with first trimester miscarriage.

Methods: This prospective cohort study included 35 women, who were diagnosed with miscarriage (patient group) and 35 healthy pregnant women below 14 weeks of gestation (control group), who did not report any complaints. 8-OHdG levels were measured with a competitive ELISA (Enzyme-Linked ImmunoSorbent Assay) high sensitivity kit and MDA levels were also measured in both groups.

Results: There wasn't difference in terms of complete blood count, thyroid-stimulating hormone (TSH), homocysteine values, parity, age, body mass index (BMI) and gestational age between the groups. Serum 8-OHdG and MDA levels were significantly higher in the patient group $(\mathrm{p}=0.001)$. A moderate positive significant correlation between the gestational week and MDA values and a weak but significant positive correlation between 8-OHdG values and gestational week were detected in the patient group.
\end{abstract}

Conclusion: 8-OHdG and MDA could play a role in the etiopathogenesis of first-trimester miscarriage. However, this role must be further delineated in large-scaled studies for early diagnosis and management of this condition.

Keywords: Oxidative Stress, malondialdehyde, 8-hydroxy-2-deoxyguanosine, miscarriage, pregnancy.

DOI: 10.5798/dicletip.706022

Correspondence / Yazıșma Adresi: Reyhan Gündüz, University of Dicle, School of Medicine, Department of Obstetrics and Gynecology Diyarbakir / Turkey e-mail: ryhn.gunduz@gmail.com 


\section{Missed Abortuslarda 8-Hidroksi-2-Deoksiguanozin Ve Malondialdehit Seviyelerinin Değerlendirilmesi: Prospektif Kohort Çalışması}

Öz

Amaç: Bu çalışma missed abortusu olan hastalarda 8-hidroksi-2-deoksiguanozin (8-OHdG) ve malondialdehit (MDA) seviyelerini değerlendirmeği amaçladı.

Metods: Bu prospektif kohort çalışmasına missed abortus tanısı alan 35 kadın (hasta grubu) ve herhangi bir şikayeti olmayan 14 hafta altı 35 sağlıklı gebe kadın (kontrol grubu) dahil edildi. 8- OHdG seviyeleri yarışmalı sensitivitesi yüksek ELISA (Enzyme-Linked ImmunoSorbent Assay) kiti ile ölçüldü ve MDA seviyeleri de her iki grupta ölçüldü.

Bulgular: Gruplar arasında tam kan sayımı, tiroid stimulan hormon (TSH), homosistein değerleri, parite, yaş, vücut kitle indeksi (VKI) ve gebelik yaşı açısından fark yoktu. Hasta grubunda serum 8-OHdG ve MDA düzeyleri önemli ölçüde daha yüksek bulundu ( $\mathrm{p}=0.001)$. Hasta grubunda, gebelik haftası ile MDA değerleri arasında orta derecede pozitif anlamlı bir korelasyon vardı ve 8-OHdG değerleri ve gebelik haftası arasında zayıf ama anlamlı pozitif bir korelasyon olduğu tespit edildi.

Sonuç: 8-OHdG ve MDA missed abortus etiyopatogenezinde rol oynayabilir. Ancak, bu durumun erken teşhis ve tedavisi için geniş ölçekli çalışmalarda bu rol daha fazla tanımlanmalıdır.

Anahtar kelimeler: Oksidatif stres, malondialdehit, 8-hidroksi-2-deoksiguanozin, missed abortus, gebelik.

\section{INTRODUCTION}

Abortion is the premature exit of an immature fetus from the uterus, which is unable to survive in the extra-uterine environment and termination of pregnancy ${ }^{1}$. The rate of clinically detected fetal loss in the first three months of gestation has been reported to be $10-12 \%$ in well-documented retrospective and prospective studies ${ }^{2}$.

Although the etiology has not been fully elucidated for missed abortion in which intrauterine fetal demise is not accompanied by bleeding and cervical dilation that occur in other types of abortion, a set of maternal and fetal factors can be listed and chromosomal anomalies, infections, immunologic factors, endocrine disorders, drug use, and environmental factors are at the top of the list.

Oxidative stress is thought to affect the pathophysiology of many diseases. Free radicals generated by oxidative stress exert toxic effects on carbohydrates, proteins, lipids, and deoxyribonucleic acid (DNA) metabolism ${ }^{3}$. Free radicals damage cell structures and extracellular matrix elements, but they can also cause genetic damage through DNA damage ${ }^{4}$. 8hydroxy-2-deoxyguanosine (8-OHdG) is generated by the oxidative modification of guanine found in the DNA structure ${ }^{5}$. It works as a marker for oxidative DNA damage cause it is produced when DNA is damaged.

Also, lipid peroxidation (LPO) mediated by free oxygen radicals is an important cause of damage to the cell membrane. Non-enzymatic LPO directly damages the cell membrane and indirectly damages other cellular components through the production of reactive aldehydes ${ }^{6-8}$. LPO's final product is Malondialdehyde (MDA) and used to evaluate the level of oxidative damage.

As far as we investigate, no study investigates the oxidative stress levels end products 8-OHdG and MDA in patients with first-trimester miscarriage. Thus, we aimed at investigating the oxidative stress levels end products $8-\mathrm{OHdG}$ and MDA. 


\section{METHODS}

The present study included 35 women that were diagnosed with first-trimester miscarriage (patient group) between February 2014 and October 2014 and 35 healthy pregnant women (first trimester) below 14 weeks of gestation (control group) without any complaints. The study was carried at the Gynecology Clinics at Şahinbey Hospital of Gaziantep University Faculty of Medicine, which is a tertiary referral center in Southeastern Turkey serving a population of 6 million people. The women included in the study were provided information about the study and their consents were obtained. The study has received approval by the Ethics Committee of Gaziantep University Faculty of Medicine with a decision number of 448 on December 17th, 2013. Exclusion criteria of the study were patients with an established cause for recurrent pregnancy loss such as antiphospholipid syndrome, diabetes mellitus, hypothyroidism, and other autoimmune or endocrine complications and abortions associated with an abnormal karyotype result.

The gestational week was calculated according to the last menstrual period in patients with a regular cycle (LMP) or identified gestational sac or crown-rump length (CRL) with transvaginal ultrasonography. Ultrasound examinations were performed with a 7.5-MHz transvaginal probe (Applio®, Toshiba, Japan). The gestational age was depended on the measurement of CRL in patients in whom the last menstrual period was unclear or there was more than the one week difference between calculations depended on LMP and ultrasonography (USG). Fetal heart rate was detected in all patients in the control group and no abnormal USG finding was observed. There was an embryo in the miscarriage group, but no fetal heart rate was observed.

A detailed medical history was obtained upon admission in the two groups, and systemic and obstetric examinations were performed by the same operator to avoid inter-observer variability. Demographic data (age, parity, abortion, and curettage), body mass index (BMI) depended on the weight and height measurement, complaints, LMP, and previous history of pregnancy, if any, were recorded. Laboratory tests included blood count parameters (hemoglobin, white blood cells, and platelets), fasting blood glucose, human chorionic gonadotropin (hCG), progesterone, thyroid-stimulating hormone (TSH), and homocysteine levels. CRL was measured on USG in each patient and fetal heart rate was monitored.

\section{8-OHdG Measurement}

Northwest kit (Northwest, NWLSS 8-OHdG ELISA High Sensitivity kit $®$, Vancouver, Canada) was used to measure serum 8-0HdG levels, which was a marker of oxidative damage. Northwest kit is a competitive ELISA (Enzymelinked immunosorbent assay) kit and it is appropriate to measure oxidative damage in DNA molecules in the serum and plasma. ELISA was performed at the Department of Biochemistry at the Gaziantep University Faculty of Medicine?

\section{MDA Measurement}

MDA levels were estimated by Hunter et al. ${ }^{10}$. After vortexing a mixture of $0.5 \mathrm{ml}$ of $35 \%$ trichloroacetic acid (TCA) $+0.5 \mathrm{ml}$ serum, $0.5 \mathrm{ml}$ Tris/HCl buffer (50 mM; pH 7.4) was added and mixed further. And then incubated at room temperature for 10 minutes. After adding one $\mathrm{ml}$ of $0.75 \%$ thiobarbituric acid (TBA) in $2 \mathrm{M}$ $\mathrm{Na} 2 \mathrm{SO} 4$ heating procedure was performed to the mixture at $100^{\circ} \mathrm{C}$ for $45 \mathrm{~min}$. After cooling this mixture, $1 \mathrm{ml}$ of $70 \%$ TCA was instilled. And then it was vortexed and centrifuged at $950 \times \mathrm{g}$ for 10 minutes. The absorbance of the supernatant was detected at $530 \mathrm{~nm}$. Total TBAreactive materials were enounced as MDA, using a molar extinction coefficient for MDA of 
1.56×105 cm-1M-1. Biochemical measurements were achieved at room temperature using a Cecil CE 3041 spectrophotometer (Cambridge, UK).

\section{Statistical Analysis}

The student's t-test was used to compare numeric variables with normal distribution and the Student t-test (for normal data) and MannWhitney U (for non-normal data) tests were used to compare numerical variables between the groups. The chi-square test was used to the relationship between categorical variables. Correlations between variables were displayed by Superman's rank correlation analysis. A pvalue of less than 0.05 was understood statistically significant. Statistical analysis which was performed with Statistical Package for the Social Sciences for Windows (SPSS, version 11.5, Chicago, IL, USA) was used to data analysis.

\section{RESULTS}

A total of 70 women (35 patients and 35 controls) that did not have any of the exclusion criteria were included in this study. The parameters of complete blood count, TSH and homocysteine values, age, parity, gestational age, BMI values based on height and weight measurements, weren't significantly different between groups and results are shown in Table I.

The mean level of 8-OHdG in the patient group was higher than controls and this situation was statistically significant $(\mathrm{p}<0.001)$ (Table I). Also, mean levels of MDA were significantly higher in the patient group in comparison to controls $(\mathrm{p}<0.001)$ (Table I). Mean levels of progesterone were significantly higher in controls in comparison to patients $(\mathrm{p}<0.001)$ (Table I). Mean hCG levels were also significantly higher in controls than patients $(\mathrm{p}<0.001)$
Table I. Comparison of the groups according to age, gestational age, parity, BMI, and laboratory values.

\begin{tabular}{|c|c|c|c|}
\hline Variable & $\begin{array}{l}\text { Control } \\
\text { Group } \\
(n=35)\end{array}$ & $\begin{array}{l}\text { Patient Group } \\
\qquad(n=35)\end{array}$ & $\mathbf{p}^{*}$ \\
\hline Age & $30.46 \pm 6.93$ & $30.37 \pm 6.96$ & $0.959^{\#}$ \\
\hline $\begin{array}{l}\text { Gestational } \\
\text { Age (week) }\end{array}$ & $8.5 \pm 1.84$ & $9.09 \pm 1.79$ & $0.169^{\#}$ \\
\hline Parity & $2(0-7)$ & $1(0-4)$ & $0.325 \S$ \\
\hline BMI $\left(\mathrm{kg} / \mathrm{m}^{2}\right)$ & $24.35 \pm 2.55$ & $24.15 \pm 2.78$ & $0.755^{\#}$ \\
\hline $\begin{array}{c}\text { Hemoglobin } \\
\text { (g/dl) }\end{array}$ & $\begin{array}{c}12.52 \pm \\
1.36\end{array}$ & $12.86 \pm 1.36$ & $0.293^{\#}$ \\
\hline $\begin{array}{l}\text { Leukocyte } \\
\left(\times 10^{3} / \mathrm{ml}^{2}\right)\end{array}$ & $\begin{array}{l}8.188 \pm \\
2592.72\end{array}$ & $\begin{array}{l}8.890 \pm \\
2848.58\end{array}$ & $0.285^{\#}$ \\
\hline $\begin{array}{l}\text { Platelets } \\
\left(\mathrm{x} 10^{6} / \mathrm{ml}\right)\end{array}$ & $\begin{array}{l}264.028 \pm \\
82228.69\end{array}$ & $\begin{array}{l}247.371 \pm \\
68719.41\end{array}$ & $0.361^{\#}$ \\
\hline TSH (uIU/ml) & $1.18 \pm 0.82$ & $1.42 \pm 0.61$ & $0.169 \#$ \\
\hline $\begin{array}{c}\text { Homocysteine } \\
\text { (umol/L) }\end{array}$ & $8.89 \pm 6.56$ & $9.85 \pm 7.49$ & $0.571^{\#}$ \\
\hline $\begin{array}{c}\text { Progesterone } \\
(\mathrm{ng} / \mathrm{ml})\end{array}$ & $26.2 \pm 13.25$ & $15.69 \pm 11.55$ & $0.001^{\#}$ \\
\hline $\begin{array}{c}\text { hCG } \\
(\mathrm{mIU} / \mathrm{ml})\end{array}$ & $\begin{array}{c}55876.11 \pm \\
39794.62\end{array}$ & $\begin{array}{c}19773.71 \pm \\
19447.07\end{array}$ & $0.001^{\#}$ \\
\hline $\begin{array}{l}\text { 8-0HdG } \\
\text { (ng/ml) }\end{array}$ & $6.31 \pm 2.61$ & $10.01 \pm 2.44$ & $0.001^{\#}$ \\
\hline $\begin{array}{c}\text { MDA } \\
(\mu \mathrm{mol} / \mathrm{L})\end{array}$ & $8.72 \pm 5.27$ & $14.39 \pm 6.05$ & $0.001^{\#}$ \\
\hline
\end{tabular}

BMI: Body mass index

TSH: Thyroid-stimulating hormone

hCG: Human chorionic gonadotropin

8-OHdG: 8-hydroxy-2-deoxyguanosine

MDA: Malondialdehyde

* A p-value below 0.05 was considered as significant

There wasn't significant correlation in the intragroup analysis of serum 8-OHdG, MDA and homocysteine levels in the control group. A moderate positive significant correlation between a gestational week and MDA values $(\mathrm{r}=0.443, \mathrm{p}=0.008)$ (Figure 1) and a significant positive correlation between $8-0 \mathrm{HdG}$ values and gestational week were detected in the patient group ( $\mathrm{r}=0.392, \mathrm{p}=0.02)$ (Figure 2). 


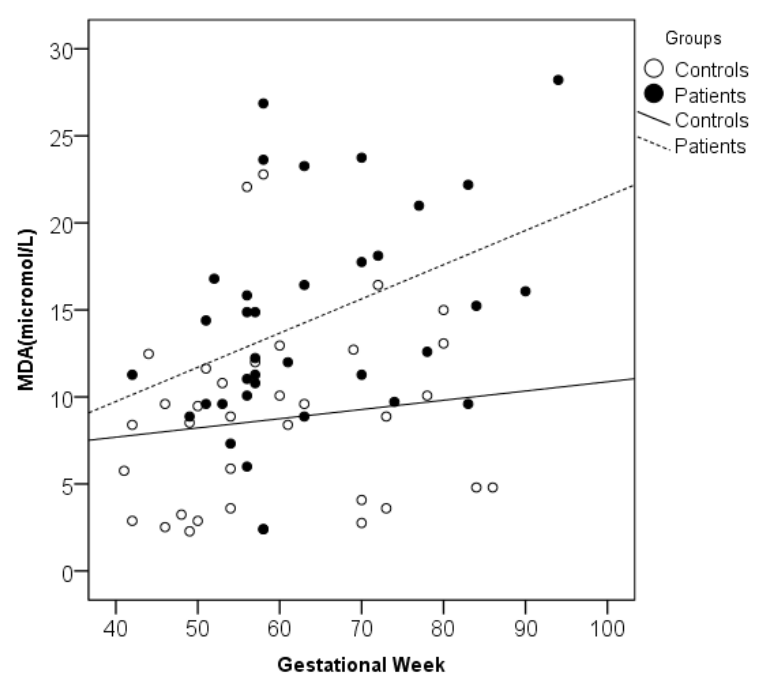

Figure 1. Correlation of MDA to the gestational week in both groups.

MDA: Malondialdehyde

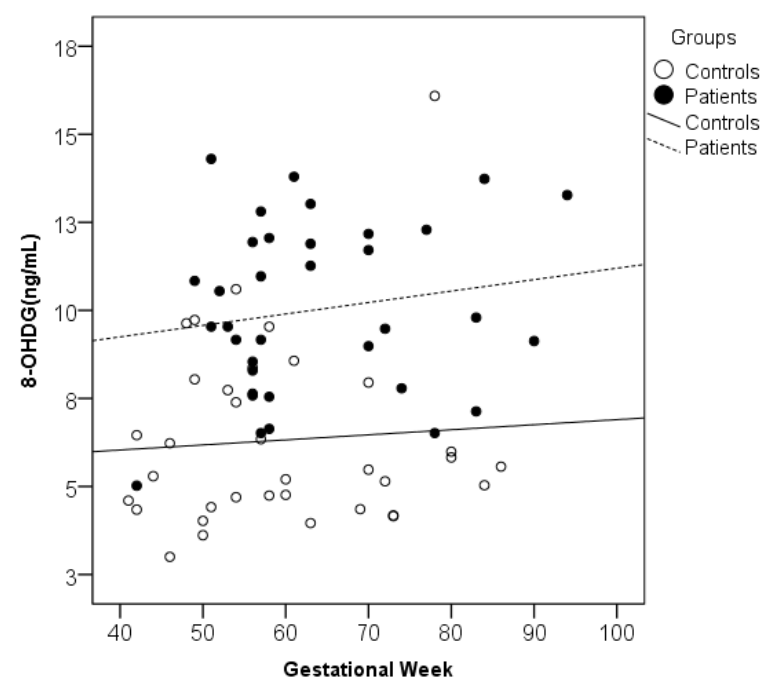

Figure 2. Correlation of $8-0 H d G$ to the gestational week in both groups.

8-OHdG: 8-hydroxy-2-deoxyguanosine

\section{DISCUSSION}

This study aimed to evaluate 8-OHdG and MDA levels in patients with first-trimester miscarriage. Serum 8-OHdG and MDA levels were significantly higher in the patient group $(\mathrm{p}=0.001)$. There was a moderate positive significant correlation between a gestational week and MDA values in the patient group and there was a weak but significant positive correlation between $8-\mathrm{OHdG}$ values and gestational week in the patient group.

Spontaneous loss of a pregnancy can be classified clinically using different methods. Commonly used subgroups include abortus imminence, abortus insipient, incomplete and complete abortions. Miscarriage is a condition in which intrauterine fetal demise is not accompanied by bleeding and cervical dilation that occur in other types of abortion ${ }^{11}$.

Miscarriage can show a relationship with various etiologic factors. The factors such as chromosomal anomalies, malformations, immunologic factors, endocrine disorders, and environmental factors may be the cause of miscarriage; however, investigations toward detecting the etiology of miscarriage fail to elucidate the underlying physiopathologic mechanisms in half of the cases ${ }^{12-13}$. Oxidative stress is currently a hot topic and some authors suggest that it may have a key role in etiology and pathogenesis of various obstetric conditions ${ }^{14-20}$.

In a study by Maisonneuve et al. ${ }^{14}$, oxidized lowdensity lipoprotein and MDA levels were evaluated as the marker of oxidative stress in cord blood of dichorionic twin pairs, with one co-twin with intrauterine growth restriction (IUGR). There were more abnormal Doppler ultrasound findings, more vascular disease and higher levels of MDA were detected in the IUGR group compared to the controls ${ }^{14}$. These substances affect membrane permeability and lead to excessive intracellular $\mathrm{Ca}+2$ accumulations. Dysfunctional cell membrane leads to cell swelling and cellular death. MDA measurement in biologic materials is used as the indicator of lipid peroxide levels.

One study evaluated MDA and antioxidant enzyme levels in sera of preeclamptic women in the second and third trimesters of pregnancy ${ }^{15}$. The levels of MDA were higher in the preeclamptic group compared to the controls, 
particularly in the third trimester, while superoxide dismutase levels were lower ${ }^{15}$. MDA could affect the etiology and pathogenesis of miscarriage.

A recent study compared $8-0 \mathrm{HdG}$ and 8isoprostane levels between women having fullterm and preterm babies based on the assumption that maternal oxidative stress could be important in preterm delivery and the results suggested that these parameters could be important in understanding the mechanisms of preterm delivery ${ }^{16}$.

The studies that evaluated MDA and 8-OHdG levels to understand the relationship between oxidative stress and prematurity and birth weight found significantly higher 8-OHdG and MDA levels in cord blood of preterm babies with low birth weight ${ }^{17}$.

Several studies have reported that markers of oxidative DNA damage and oxidative stress, 8OHdG, and MDA, respectively, could affect the etiology and pathogenesis of the different diseases. One study was reported that preterm low-birth-weight newborns were higher 8OHdG and MDA levels in the patient group than controls $^{17}$. Another study, they found maternal urinary 8-OHdG levels were higher than controls and increase in early pregnancy urinary 8-OHdG levels were as relevant with increased gestational diabetes mellitus (GDM) risk $^{19}$. Therefore, they evaluated their levels in patients with first-trimester miscarriage and reported that levels of both are significantly increased when compared with controls and most of them quantified the products of lipid peroxidation (mainly MDA) and contrasted them with the activity of antioxidant enzymes or antioxidants levels. In the results obtained, they reported that there is an imbalance between the high amount of free radicals and insufficient antioxidant activity. In this study, we found 8-OHdG levels in the patient group were higher than the controls. In addition, we showed that there was a significant positive correlation between a gestational week and 8OHdG values in the patient group.

The increased 8-OHdG levels in the urine were related with an increased incidence of GDM in pregnant women before twenty weeks of gestation ${ }^{18}$. The present study found higher serum 8-OHdG levels and fasting blood glucose in the patient group compared to the control group. Due to the exclusion of patients with GDM and similar systemic disorders and based on the findings of the study by Qui et al.18, monitoring of these patients for the development of GDM in the forthcoming weeks of gestation may be suggested.

In the study by Peter Stein et al. ${ }^{19}$, the relationship between the urinary levels of the markers of oxidative stress in the early periods of pregnancy and the course of pregnancy, and low 8-OHdG levels were suggested to be relevant with low birth weight and shorter duration of pregnancy. One of the limitations of this study is that the evaluation of urinary 8OHdG levels was not planned. Also, the relatively small number of patients and controls may be criticized.

In the study by Onan et al. ${ }^{21}$, it has been shown that the lipid peroxidation levels may be a more sensitive indicator of intrapartum distress than results of acid-base studies.

Progesterone is a crucial hormone for maintenance of a normal pregnancy and serum progesterone levels below $5 \mathrm{ng} / \mathrm{mL}$ is a useful sign for non-viable pregnancies but, was unable to differentiate ectopic pregnancy from abnormal intrauterine pregnancy ${ }^{20}$. Progesterone levels in patients with miscarriage in the our study were lower compared to the subjects in the control group $(\mathrm{p}<0.001)$ as expected. Also, hCG levels were lower in the miscarriage group as an expected consequence of a decreased number of viable chorion villi and an associated decrease in hCG 
levels that are found in the pathogenesis of miscarriage.

The DNA damage was connected to the severity of disease in the patients. Oxidative damage to DNA has been associated with several pathologies including autoimmune, neurodegenerative, cardiovascular, and neoplastic diseases. It has been reported increased DNA damage, increased TOS levels, and decreased TAS levels in the patients. DNA damage is associated with oxidative stress. Therefore, this suggests that DNA damage may be depended on insufficient antioxidant capacity and excessive ROS generation, which contributes to the pathogenesis of the disease in patients $^{22}$. Thus, the finding supports the hypothesis of oxidative stress involvement in patients with first-trimester miscarriage.

In conclusion, significantly higher $8-\mathrm{OHdG}$ and MDA levels were found in the serum of the patient group when compared to controls in our study. As 8-OHdG, oxidative DNA damage marker, and MDA, marker of lipid peroxidation, there is an evident need for further randomized, prospective, large-scale studies to elucidate etiopathological mechanisms and to establish the clinical utility of 8-OHdG and MDA testing in serum, urine, trophoblastic tissue, and other body tissues and fluids in the early diagnosis of first-trimester miscarriage.

Ethics Committee Approval: The study has received approval by the Ethics Committee of Gaziantep University Faculty of Medicine with a decision number of 448 on December 17 th, 2013.

Conflict of İterest: There is no conflict of interest and funding.

Financial Disclosure: This study was done with the support of BAP project.

\section{REFERENCES}

1. Cunningham FG, Leveno KJ, Bloom SL, et al. Williams Obstetrics, 24 th ed. NewYork: McGraw-Hill, 2014.

2. Simpson JL, Carson SA. Causes of fetal loss. In; Gray R, Leridon L, Spira F (eds). Symposium on Biological and Demographic Determinants of Human Reproduction. Oxford, Oxford University. 1993; 287.

3. Gergerlioglu HS, Savas HA, Bulbul F, et al. Changes in nitric oxide level and superoxide dismutase activity during antimanic treatment. Prog Neuropsychopharmacol Biol Psychiatry. 2007; 31: 697-702.

4. Valko M, Rhodes CJ, Moncol J, Izakovic M, Mazur M. Free radicals, metals and antioxidants in oxidative stress-induced cancer. Chemicobiological interactions. 2006; 160: 1-40.

5. Long JD, Matson WR, Juhl AR, Leavitt BR, Paulsen JS. PREDICT-HD Investigators and Coordinators of the Huntington Study Group. $80 \mathrm{HdG}$ as a marker for Huntington disease progression. Neurobiology of Disease. 2012; 625-34.

6. Kaçmaz A, Polat A, User Y, et al. Octreotide improves reperfusion-induced oxidative injury in acute abdominal hypertension in rats. J Gastrointest Surg. 2004; 113-9.

7. Okutan H, Savas C, Delibas N. The antioxidant effect of melatonin in lung injury after aortic occlusion-reperfusion.

Interact

CardiovascThorac Surg. 2004; 3: 519-22.

8. Nielsen F, Mikkelsen BB, Nielsen JB, Andersen HR, Grandjean P. Plasma malondialdehyde as biomarker for oxidative stress: Reference interval and effects of life-style factors. Clin Chem. 1997; 43: 1209-14.

9. Altuntaş $\mathrm{H}$, Bayram $\mathrm{F}$, Bitgen $\mathrm{N}$, et al. Increased Chromosomal and Oxidative DNA Damage in Patients with Multinodular Goiter 
and Their Association with Cancer. Int J Endocrinol. 2017; Article ID 2907281.

10. Hunter MI, Nlemadim BC, Davidson DL. Lipid peroxidation products and antioxidant proteins in plasma and cerebrospinal fluid from multiple sclerosis patients. Neurochem Res. 1985; 10: 1645-52.

11. Schorge JO, Schaffer JI, Halvorson LM, et al. Williams Gynecology, 2nd ed. NewYork: McGraw-Hill, 2010.

12. Li TC, Makris M, Tomsu M, Tuckerman E, Laird S. Recurrent miscarriage: aetiology, management, and prognosis. Hum Reprod Update. 2002; 8: 463-81.

13. Wilcox AJ, Weinberg CR, O'Connor JF, et al. Incidence of early loss of pregnancy. N Engl J Med. 1988; 319: 189-94.

14. Maisonneuve E, Delvin E, Ouellet A, et al. Oxidative conditions prevail in severe IUGR with vascular disease and Doppler anomalies. J Matern Fetal Neonatal Med. 2015; 28: 1471-5.

15. Atiba AS, Abbiyesuku FM, Adekanle DA, et al. Malondialdehyde and antioxidant enzymes in second and third trimesters of pre-eclamptic Nigerian women. Niger Postgrad Med J. 2014; 21: $150-4$.

16. Ferguson KK, McElrath TF, Chen YH, et al. Repeated measures of urinary oxidative stress biomarkers during pregnancy and preterm birth. Am J Obstet Gynecol. 2015; 212: 208.
17. Negi R, Pande D, Kumar A, Khanna RS, Khanna HD. In vivo oxidative DNA damage and lipid peroxidation as a biomarker of oxidative stress in preterm low-birthweight infants. J Trop Pediatr. 2012; 58: 326-8.

18. Qiu C, Hevner K, Abetew D, Enquobahrie DA, Williams MA. Oxidative DNA damage in early pregnancy and risk of gestational diabetes mellitus: A pilot study. Clinical biochemistry. 2011; 44: 804-8.

19. Peter Stein T, Scholl TO, Schluter MD, et al. Oxidative stress early in pregnancy and pregnancy outcome. Free radical research. 2008; 42: 841-8.

20. Mol BW, Lijmer JG, Ankum WM, Van der Veen F, Bossuyt PM. The accuracy of single serum progesterone measurement in the diagnosis of ectopic pregnancy: a metaanalysis. Hum Reprod Nov. 1998; 13: 3220-7.

21. Onan A, Kurdoglu M, Sancak B, Bukan N, Yildirim M. Lipid peroxidation in nuchal cord cases: implication for fetal distress. J Matern Fetal Neonatal Med. 2009; 22: 254-8.

22. Singh AK, Pandey P, Tewari M, et al. Free radicals hasten head and neck cancer risk: $\mathrm{A}$ study of total oxidant, total antioxidant, DNA damage, and histological grade. J Postgrad Med. 2016; 62: 96-101. 